\title{
HAK WARIS ANAK YANG DILAHIRKAN MELALUI PERJANJIAN SUROGASI
}

\author{
Putu Nita Yulistian, I Nyoman Putu Budiartha, I Wayan Arthanaya \\ Fakultas Hukum Universitas Warmadewa, Denpasar-Bali, Indonesia
}

\begin{abstract}
Abstrak
Berkembangnya teknologi dalam dunia medis memunculkan metode surogasi sebagai alternatif bagi pasangan suami-istri yang tidak bisa mempunyai keturunan karena indikasi medis. Surogasi adalah perjanjian antara seorang wanita dengan pihak suami-istri untuk menjadi hamil dengan pendonoran embrio pihak suami-istri ke dalam rahim wanita tersebut dan kelak anak yang dilahirkan diserahkan pada pihak suami-istri yang melakukan perjanjian ini. Hal ini menimbulkan isu hukum yaitu bagaimana keberadaan perjanjian surogasi menurut undang-undang kesehatan dan KUHPerdata serta bagaimana hak waris anak yang lahir akibat perjanjian surogasi. Penelitian ini menggunakan penelitian normatif dengan pendekatan perundang-undangan dan konseptual dengan menggunakan bahan hukum primer, skunder dan tersier. Hasil penelitian ini menunjukkan bahwa keberadaan perjanjian surogasi tidak terdapat secara khusus, namun berdasarkan logika argumentum a contrario, pasal 127 ayat (1) huruf a Undang-Undang Kesehatan, pasal 40 ayat (2) dan pasal 43 ayat (3) huruf b Peraturan pemerintah tentang kesehatan reproduksi melarang praktik surogasi di Indonesia dan perjanjian surogasi dinyatakan tidak sah menurut pasal 1320 KUHPerdata karena tidak memenuhi syarat objektif. Jika anak tersebut lahir, menurut Undang-Undang Perkawinan, anak tersebut berhak mewaris kepada suami sah wanita surrogate atau kepada wanita surrogate dan keluarganya. Namun, apabila anak tersebut diangkat oleh orang tua biologisnya maka putuslah hubungan perdata anak tersebut kepada orang tua kandungnya dan berhak mewaris kepada orang tua angkatnya dalam hal ini orang tua biologis anak tersebut.
\end{abstract}

Kata Kunci: Hak Waris, Anak, Perjanjian Surogasi

\begin{abstract}
The development of technology in the medical world has led to surrogation methods as an alternative for married couples who cannot have children due to medical indications. Surrogation is an agreement between a woman and the husband and wife to become pregnant by donating the embryo of the husband and wife into the woman's womb and the child born is handed over to the husband and wife who make this agreement. This raises legal issues, namely how the existence of a surrogation agreement according to the health law and the Civil Code and how the inheritance rights of children born as a result of the surrogation agreement. This study uses normative research with a statutory and conceptual approach using primary, secondary and tertiary legal materials. The results of this study indicate that the existence of a surrogation agreement does not exist specifically, but based on the logic of argumentum a contrario, article 127 paragraph (1) letter a of the Health Law, article 40 paragraph (2) and article 43 paragraph (3) letter b Government regulations concerning reproductive health prohibits the practice of surrogation in Indonesia and the surrogation agreement is declared invalid according to article 1320 of the Civil Code because it does not meet the objective requirements. If the child is born, according to the Marriage Law, the child has the right to inherit to the surrogate woman's legal husband or to the surrogate woman and her family. However, if the child is adopted by the biological parent, the civil relationship between the child and the biological parent will be cut off and the right to inherit from the adoptive parent, in this case the biological parent of the child.
\end{abstract}

Keywords: Inheritance Rights, Children, Surrogation Agreement

\section{PENDAHULUAN}

Perkembangan zaman yang semakin modern memacu teknologi di dunia untuk selalu berinovasi dalam memudahkan kehidupan manusia. Temuan-temuan baru yang dihasilkan dari perkembangan dan inovasi teknologipun semakin banyak bermunculan dan semakin memudahkan kehidupan manusia. Salah satunya adalah perkembangan teknologi pada bidang kedokteran yang menemukan metode baru yaitu program bayi tabung atau yang biasa disebut inseminasi buatan atau In Vitro Fertilization yang ditemukan sekitar tahun 1970an. Penemuan ini dikembangkan dengan tujuan untuk membantu permasalahan pasangan suami istri yang tidak bisa mendapatkan keturunan dengan cara alami sehingga diperlukannya cara khusus agar embrio dapat berkembang dengan baik. 
Sejalan dengan penemuan program bayi tabung atau inseminasi buatan atau In Vitro Fertilization yang semakin pesat tersebut, muncul permasalahan baru yaitu adanya wanita yang tidak memiliki rahim atau tidak dapat menjalani proses kehamilan karena suatu indikasi medis. Sehingga muncullah istilah Surrogate Mother yang memanfaatkan metode program bayi tabung atau inseminasi buatan atau In Vitro Fertilization.

Surrogate Mother adalah istilah untuk wanita yang bersedia menjadi ibu pengganti yaitu bersedia mengandung dan merawat embrio dari sel sperma dan ovum pasangan suami istri lain yang tidak bisa mempunyai keturunan secara alami karena suatu indikasi medis dengan cara didonorkan ke dalam rahim Surrogate Mother tersebut dan nantinya Surrogate Mother tersebut bersedia mengembalikan bayi yang dilahirkan kepada pasangan suami istri pemilik sel sperma dan ovum.

Berkaitan dengan isu surogasi sebagai sebuah cara memperoleh keturunan, berikut ini beberapa penelitian yang telah membahasnya, seperti Arvidsson, Johnsdotter, Emmelin, \& Essén (2019); Chiang \& Chou (2018); Crockin, Edmonds, \& Altman (2020); González (2020); Klock \& Lindheim (2020); Tereshchenko, dkk., (2015). Agar ibu pengganti tersebut bersedia mengandung, merawat kandungan, melahirkan dan mengembalikan bayi yang lahir dikemudian hari, maka dalam kenyataannya di masyarakat, timbullah suatu perikatan antara ibu pengganti dan suami istri tersebut yang kini disebut dengan gestational agreement, surrogacy agreement atau dalam bahasa Indonesia diartikan sebagai perjanjian surogasi atau perjanjian sewa rahim.

Perjanjian surogasi adalah perjanjian antara dua pihak yang dalam hal ini adalah wanita yang bersedia menjadi ibu pengganti dan pasangan suami istri yang dalam perjanjian tersebut memuat hak dan kewajiban masing-masing pihak diantaranya wanita sebagai ibu pengganti bersedia digunakan rahimnya untuk mengandung,merawat kandungan, melahirkan dan mengembalikan bayi yang lahir kepada pasangan suami istri pendonor embrio dengan mendapatkan hak yaitu berupa imbalan materi berupa uang atau imbalan lain yang ditentukan. Sedangkan pasangan suami istri berkewajiban untuk membiayai proses pendonoran embrio, perawatan janin, persalinan, dan memberikan imbalan kepada wanita yang bersedia menjadi ibu pengganti dan nantinya berhak mendapatkan anak yang telah dilahirkan ibu pengganti tersebut.

Perjanjian semacam ini sudah dilakukan di beberapa negara bahkan ada negara yang sudah melegalkan perjanjian sewa rahim ini. Di Indonesia sendiri perjanjian surogasi ini dilakukan secara diam-diam bahkan di salah satu sosial media banyak yang ingin menyewakan rahimnya ataupun menyewa rahim seseorang karena suatu alasan tertentu.

Aturan mengenai perjanjian surogasi ini belum diatur secara mengkhusus dalam hukum positif di Indonesia. Dengan semakin tingginya minat masyarakat untuk menyewakan rahimnya atau menyewa rahim seseorang ini maka dikhawatirkan akan menimbulkan permasalah-permasalahan hukum yang dalam hal ini menyangkut pihak penyewa rahim dan pihak yang menyewakan rahimnya.

Masalah-masalah hukum yang dimungkinkan akan timbul dari perjanjian surogasi ini adalah tidak sahnya perjanjian karena rahim bukanlah objek suatu perjanjian dan perjanjian tersebut dianggap tidak pernah ada sehingga ditakutkan adanya kerugian dari pihak-pihak yang bersangkutan. Masalah hukum selanjutnya adalah tentang hak waris anak tersebut, kemanakah anak tersebut akan berhak mewaris. Oleh karena itu, penelitian ini bertujuan untuk menganalisis keberadaan perjanjian surogasi menurut Undang-Undang Kesehatan dan KUHPerdata dan mengetahui hak waris anak yang dilahirkan melalui perjanjian surogasi.

\section{METODE PENELITIAN}

Tipe penelitian yang digunakan adalah penelitian hukum normatif. Pendekatan yang digunakan dalam penelitian ini adalah pendekatan perundang-undangan (statute approach) yang berupa legislasi dan regulasi yang dibentuk oleh lembaga negara atau pejabat negara yang berwenang dan mengikat secara umum, dan juga menggunakan pendekatan konseptual (conseptual approach). Penelitian normatif tentu harus menggunakan pendekatan perundang-undangan karena yang diteliti adalah berbagai aturan hukum yang menjadi fokus sekaligus tema sentra suau penelitian (Ibrahim, 2013:302).

Bahan hukum yang digunakan dalam penelitian ini adalah bahan hukum yang diperoleh dari penelitian kepustakaan (library research), yaitu : 1). Bahan Hukum Primer. Adapun bahan bukum primer yang digunakan dalam penelitian ini adalah bahan hukum yang bersumber dari peraturan perundang-undangan yang berkaitan dengan pokok permasalahan yang akan dibahas. 2) Bahan Hukum Skunder. Bahan hukum skunder adalah bahan hukum yang memberikan penjelasan terhadap 
bahan hukum primer, seperti literatur, artikel, hasil penelitian, dan lainnya yang dapat mendukung bahan hukum primer. 3) Bahan Hukum Tersier. Bahan hukum tersier adalah bahan hukum yang dapat memberikan penjelasan terhadap bahan hukum primer dan skunder yaitu seperti kamus besar bahasa Indonesia, kamus hukum, dan lain sebagainya.

Pengumpulan bahan hukum dilakukan dengan cara inventirasi sehingga memudahkan penelusuran bahan-bahan hukum yang akan digunakan. Bahan hukum dikumpulkan dengan studi dokumentasi yaitu dengan melakukan pencatatan atau pengutipan terhadap bahan hukum primer, skunder dan tersier yang relevan dengan topik penelitian.

Analisis bahan hukum yang digunakan dalam penelitian ini adalah dengan menggunakan metode deskriptif yaitu dengan menguraikan atau menjabarkan permasalahan, menelaah, memberikan pandangan, dan pemecahan terhadap masalah yang dikaji yang kemudian ditarik suatu kesimpulan.

\section{HASIL DAN PEMBAHASAN}

Adanya kekosongan hukum terhadap hal-hal maupun keadaan yang tidak atau belum diatur khususnya dalam metode surogasi untuk memiliki anak ini ditakutkan akan menyebabkan ketidakpastian hukum (rechtsonzekerheid) atau ketidakpastian peraturan perundang-undangan di masyarakat bahkan dapat menyebabkan terjadinya kekacauan hukum (rechtsverwarring). Artinya bahwa selama metode surogasi ini tidak diatur secara jelas dalam undang-undang manapun berarti metode ini boleh dilakukan, atau selama belum ada tata cara yang jelas dan diatur berarti bukan tidak boleh metode surogasi ini dilakukan di Indonesia.

Hal inilah yang menyebabkan kebingungan atau kekacauan dalam masyarakat mengenai aturan apa yang harus dipakai atau diterapkan dalam menentukan kelayakan praktik surogasi dalam mendapatkan anak di Indonesia.Upaya untuk mengatasi kebingungan dalam masyarakat tentang boleh tidaknya metode surogasi ini dilakukan yaitu dengan melakukan pengkajian mengenai metode surogasi pertama-tama dikaji dengan menggunakan Undang-Undang Kesehatan.

Mengingat bahwa metode surogasi ini adalah sebuah upaya kehamilan di luar cara alamiah, hal tersebut diatur dalam Undang-Undang Nomor 36 Tahun 2009 tentang Kesehatan yang tercantum pada pasal 127. Pasal 127 ayat (1) menyebutkan upaya kehamilan di luar cara alamiah hanya dapat dilakukan oleh pasangan suami istri yang sah dengan ketentuan.Salah satu ketentuan yang nya yang mendasar pada pasal 127 ayat (1) Undang-Undang Kesehatan ini dikatakan pada huruf a yaitu hasil pembuahan sperma dan ovum dari suami istri yang bersangkutan ditanamkan dalam rahim istri dari mana ovum berasal. Hal ini juga diatur kembali dalam PP Nomor 61 Tahun 2014 tentang Kesehatan Reproduksi pada pasal 40 dan Permenkes nomor 43 Tahun 2015 tentang Penyelenggaraan Pelayanan Reproduksi dengan Bantuan atau Kehamilan di Luar Cara Alamiah.

Terkait larangan menanamkan sel sperma dan ovum yang telah berkembang menjadi embrio dalam rahim wanita lain diatur pada pasal 43 ayat (3) huruf b PP Nomor 61 Tahun 2014 tentang Kesehatan Reproduksi yang menyatakan bahwa embrio dilarang ditanamkan pada rahim perempuan lain. Sehingga berdasarkan logika argumentum a contrario, metode surogasi untuk mendapatkan keturunan dilarang dilakukan di Indonesia.

Sedangkan dalam KUHPerdata penulis mengkaji keberadaan perjanjian surogasi melalui 3 aspek yaitu perjanjian surogasi menurut hukum sewa-menyewa, hukum kebendaan dan hukum perikatan atau perjanjian. Setelah mengetahui bagaimana perjanjian surogasi dipandang melalui hukum sewa menyewa dan hukum kebendaan, pengkajian diakhiri dengan menggunakan hukum perikatan atau perjanjian untuk melihat keberadaan perjanjian surogasi tersebut dalam KUHPerdata.

Tentang sewa-menyewa diatur dalam pasal 1548 KUHPerdata yang menyatakan bahwa sewa menyewa ialah suatu perjanjian, dengan mana pihak yang satu mengikatkan dirinya untuk memberikan kepada pihak yang lainnya kenikmatan dari sesuatu barang, selama suatu waktu tertentu dan dengan pembayaran sesuatu harga, yang oleh pihak tersebut belakangan itu disanggupi pembayarannya. Bila dikaitkan dengan perjanjian surogasi atau perjanjian sewa rahim, memang betul adanya bahwa perjanjian tersebut dilakukan oleh dua belah pihak dengan waktu tertentu dan pembayaran. Namun dalam hal menikmati barang yang disewa, hal tersebut tidak dinikmati secara langsung namun yang dinikmati adalah hasil akhir yaitu bayi yang dilahirkan. Namun kembali berbicara tentang barang, rahim tidak termasuk barang atau objek perjanjian yang dimaksudkan KUHPerdata. 
Untuk memperkuat pernyataan bahwa rahim bukanlah termasuk sebuah barang yang dapat dijadikan pokok suat perjanjian maka akan ditinjau melalui KUHPerdata dalam Buku Kedua tentang kebendaan pada pasal 499 KUHPerdata dinyatakan bahwamenurut paham undang-undang yang dinamakan kebendaan ialah, tiap-tiap hak yang dapat dikuasai oleh hak milik. Terjemahan bebasnya adalah benda merupakan sesuatu yang dapat menjadi hak milik. Artinya bahwa hak yang melekat atas suatu benda tersebut dapat dipertahankan oleh pemegang hak ataupun dipindah tangankan kepada pihak lain.Benda yang diatur dalam KUHPerdata adalah benda berwujud seperti kendaraan, rumah ataupun tanah yang lantas disebut dengan perjanjian nominaat. Sedangkan benda tak berwujud seperti hak paten, hak cipta dan lain-lain diatur dalam undang-undang tersendiri dan disebut perjanjian innominaat.

Dalam kasus perjanjian surogasi, tidak pantas rasanya bila rahim dikatakan sebagai benda atau barang yang dapat dipindah tangankan haknya. Walaupun kenyataannya rahim adalah berwujud dan dapat dipegang, tetapi rahim bukan barang yang dimaksudkan dalam Pasal 499 KUHPerdata dan tidak ditemukan pula kodifikasi khusus tentang rahim dalam KUHPerdata. Rahim adalah organ yang melekat dalam tubuh seorang wanita sehingga tidak layak disebut sebagai objek perjanjian namun tetap dianggap sebagai bagian dari subyek hukum karena rahim melekat dalam tubuh seorang wanita dan tidak dapat dipisahkan.

Sebelum kita mengkaji perjanjian surogasi melalui sudut hukum perikatan atau perjanjian, hendaknya kita mengetahui apa itu perjanjian surogasi. Perjanjian surogasi atau perjanjian sewa rahim adalah perjanjian seorang wanita yang mengikatkan dirinya kepada pihak lain untuk menjadi hamil dan setelah melahirkan menyerahkan anak atau bayi tersebut.

Berbicara mengenai perjanjian tentu kita mengacu pada keabsahan suatu perjanjian yang dimuat dalam pasal 1320 KUHPer yang mencantumkan syarat-syarat sahnya perjanjian. Syarat perjanjian pertama yaitu kesepakatan dan kedua yaitu kecakapan yang disebut sebagai syarat subyektif. Sedangkan syarat ketiga yaitu suatu hal tertentu dan syarat keempat yaitu suatu sebab yang halal disebut sebagai syarat obyektif.

Dalam hal syarat subyektif, perjanjian surogasi sudah memenuhi syarat yaitu bahwa diantara keduabelah pihak telah bersepakat dalam hal perjanjian sewa-menyewa rahim tersebut dan keduabelah pihak yang melakukan perjanjian telah memenuhi syarat kecakapan yaitu telah berumur di atas 21 Tahun. Namun dalam hal syarat objektif, perjanjian surogasi ini belum memenuhi syarat. Diantaranya syarat ketiga yaitu suatu hal tertentu dikarenakan hal tertentu yang dimaksudkan dalam perjanjian adalah barang yang dapat diperjualbelikan namun dalam hal surogasi, organ rahim bukanlah termasuk barang yang bisa diperjualbelikan. Syarat keempat yang belum dipenuhi adalah suatu sebab yang halal yaitu bahwa perjanjian surogasi ini telah melanggar undang-undang, sehingga karena tidak terpenuhinya syarat objektif dalam perjanjian ini, maka perjanjian surogasi ini batal demi hukum (null and void) atau dari semula dianggap tidak pernah ada dilahirkan suatu perjanjian dan tidak pernah ada suatu perikatan. Apabila perjanjian ini tetap saja dilaksanakan oleh keduabelah pihak dan suatu saat tertentu terdapat permasalahan hukum yang merugikan salah satu pihak maka pihakpihak yang dirugikan tersebut tidak dapat mengajukan gugatan ke pengadilan karena perjanjian dianggap tidak pernah ada.

Apabila perjanjian surogasi terus berlanjut dilaksanakan hingga lahirnya si anak, maka perlu dikaji status hukum anak tersebut untuk menentukan hak waris si anak kedepannya. Status anak yang lahir dari hasil perjanjian surogasi atau yang dilahirkan oleh wanita surrogate di Indonesia dikaitkan dalam Undang-Undang Republik Indonesia Nomor 1 Tahun 1974 tentang Perkawinan. Apabila wanita surrogate terikat perkawinan yang sah dengan suaminya, maka anak yang lahir tersebut merupakan anak sah dari ibu yang melahirkannya (wanita surrogate) dan bukan merupakan anak sah dari orang tua yang menitipkan benih dalam rahim wanita surrogate (Judiasih \& Dajaan, 2017:30). Namun, apabila wanita surrogate tersebut tidak terikat perkawinan, maka anak tersebut menjadi anak luar kawin atau anak yang dilahirkan di luar perkawinan yang sah.

Apabila status hukum anak tersebut adalah anak sah dari wanita surrogate dan suami wanita surrogate tersebut maka anak tersebut berhak mendapat hak waris penuh sesuai dengan hukum waris yang berlaku dari suami wanita surrogate. Hal tersebut dikaji dengan dasar hukum pasal 42 UndangUndang Republik Indonesia Nomor 1 Tahun 1974 tentang Perkawinan yang menyatakan bahwa anak yang sah adalah anak yang dilahirkan dalam atau sebagai akibat perkawinan yang sah. Pasal 250 
KUHPerdata yang menyatakan bahwa tiap-tiap anak yang dilahirkan atau ditumbuhkan sepanjang perkawinan, memperoleh si suami sebagai bapaknya.

Apabila status hukum anak tersebut adalah anak luar kawin dari wanita surrogate yang tidak sedang terikat perkawinan yang sah, maka anak tersebut berhak mendapat hak waris penuh dari ibunya atau dari wanita surrogate dan keluarga wanita surrogate. Hal tersebut dikaji dengan menggunakan pasal 43 ayat (1) Undang-Undang Republik Indonesia Nomor 1 Tahun 1974 tentang Perkawinan yang menyatakan bahwa anak yang dilahirkan di luar perkawinan hanya mempunyai hubungan perdata dengan ibunya dan keluarga ibunya.

Walaupun anak yang lahir akibat perjanjian surogasi tersebut berhak mewaris kepada ibu atau wanita surrogate dan keluarga wanita surrogate serta tidak dapat menuntut hak waris kepada ayah biologisnya, bukan berarti ayah biologisnya terbebas dari segala kewajibannya. Ayah biologis atau ayah genetik dari anak yang lahir tersebut tetap harus memberi nafkah kepada anak tersebut sesuai dengan dasar hukum yaitu Putusan Mahkamah Konstiusi Nomor 46/PUU-VIII/2010 tanggal 17 Februari 2002.

Namun bukan tidak mungkin anak hasil surogasi tersebut mewaris kepada orang tua biologisnya. Apabila dilihat dari tujuan dilakukannya perjanjian surogasi antara pasangan suami istri dengan wanita surrogate ini adalah untuk melanjutkan garis keturunan keluarga pasangan suami istri dengan menggunakan jasa sewa rahim wanita lain yang menyanggupinya, maka akan jadi tidak adil untuk pihak-pihak yang melakukan perjanjian tersebut apabila anak yang lahir akibat perjanjian surogasi mewaris pada wanita surrogate dan keluarga wanita tersebut atau kepada wanita surrogate dan suami sah wanita surrogate tersebut.

Pihak suami istri melakukan perjanjian surogasi karena mereka mempunyai hak untuk mendapatkan keturunan sesuai dengan pasal 28B ayat (1) UUD NRI Tahun 1945 walaupun pihak istri mengalami indikasi medis karena tidak bisa hamil pasangan suami istri tersebut tetap mengupayakan untuk memiliki anak biologis untuk meneruskan garis keturunan keluarganya. Sedangkan pihak wanita surrogate hanya menyediakan jasa sewa rahim dan tidak berniat untuk memiliki anak hasil surogasi tersebut.

Bila anak yang dilahirkan tersebut kehidupan dan masa depannya menjadi tanggungan pihak wanita surrogate dan keluarganya, maka akan merugikan pihak wanita surrogate itu sendiri dan juga merugikan pihak pasangan suami istri yang menggunakan jasa sewa rahim wanita surrogate, karena harapannya untuk meneruskan garis keturunan keluarga dari anak biologis yang dilahirkan dengan metode surogasi tersebut tidak bisa terlaksana akibat anak yang lahir menjadi anak dan memiliki hubungan perdata dengan wanita surrogate bukan dengan pasangan suami istri pengguna jasa sewa rahim atau orang tua biologisnya.

Agar wanita surrogate ataupun pihak suami istri (orang tua biologis) si anak hasil surogasi tidak dirugikan, maka orang tua biologis dimungkinkan untuk melakukan pengangkatan anak agar status anak tersebut menjadi anak sah dari pasangan suami istri (orang tua biologis). Mengenai pengangkatan anak diatur dalam Peraturan Pemerintah Republik Indonesia Nomor 54 Tahun 2007 tentang Pelaksanaan Pengangkatan Anak. Tujuan pengangkatan anak itu sendiri diatur pada pasal 2 yang menyatakan bahwa pengangkatan anak bertujuan untuk kepentingan terbaik bagi anak dalam rangka mewujudkan kesejahteraan anak dan perlindungan anak, yang dilaksanakan berdasarkan adat kebiasaan setempat dan ketentuan peraturan perundang-undangan.

Bila dikaitkan dengan anak yang lahir akibat perjanjian surogasi, ketika anak tersebut menjadi anak dari wanita surrogate dan semua kebutuhan hidupnya ditanggung oleh wanita surrogate dan keluarga atau suami sah dari wanita surrogate, maka dapat diduga bahwa kesejahteraan, rasa aman, dan keoentingan anak tersebut bisa saja tidak terpenuhi karena sebagian besar wanita surrogate menyewakan rahimnya untuk mendapatkan upah (uang) untuk memenuhi kebutuhannya sendiri atau memenuhi kebutuhan keluarganya.

Apabila wanita surrogate dankeluarga wanita surrogate, atau suami sah wanita surrogate tersebut memikul hak dan kewajiban sebagai pihak yang sah untuk memenuhi kebutuhan anak tersebut, dikhawatirkan akan terjadinya penyimpangan seperti penelantaran anak hasil surogasi atau tidak dipenuhinya kebutuhan-kebutuhan anak tersebut sehingga diperlukannya pengangkatan anak oleh orang tua biologisnya untuk menjamin kesejahteraan lahir dan batin serta mencegah hal-hal yang tidak adil yang dimungkinkan akan terjadi pada anak tersebut apabila berada dalam lingkungan keluarga wanita surrogate. 
Berdasarkan uraian di atas, pengangkatan anak yang dimungkinkan untuk dilakukan oleh pasangan suami istri (orang tua biologis) anak yang lahir akibat perjanjian surogsai ini termasuk dalam kategori pengangkatan anak secara langsung (Private Adoption), yaitu pengangkatan anak yang dilakukan oleh calon orang tua angkat terhadap calon anak angkat yang berada langsung dalam asuhan orang tua kandung yang hal tersebut sesuai dengan ketentuan pasal 8 huruf b Peraturan Pemerintah Republik Indonesia Nomor 54 Tahun 2007 Pelaksanaan Pengangkatan Anak.

\section{SIMPULAN DAN SARAN}

\section{Simpulan}

Keberadaanperjanjian surogasi menurut Undang-Undang Kesehatan dan KUHPerdatatidak terdapat secara mengkhusus namun secara implisit perjanjian surogasi serta praktik metode surogasi untuk memiliki keturunan dilarang dilakukan di Indonesia. Berdasarkan logika argumentum a contrario maka berdasarkan pasal 127 ayat (1) huruf a Undang-Undang Kesehatan, pasal 40 ayat (2) dan pasal 43 ayat (3) huruf b Peraturan pemerintah nomor 61 Tahun 2014 tentang kesehatan reproduksi melarang praktik surogasi yaitu penanaman embrio ke dalam rahim wanita lain selain kedalam rahim istri sah dimana ovum itu berasal. Sedangkan dalam KUHPerdata berdasarkan pasal 1320 tentang syarat sahnya perjanjian maka perjanjian surogasi tidak memenuhi syarat sahnya perjanjian dalam hal ini tidak memenuhi seluruh syarat objektif sehingga perjanjian surogasi tidak sah dan dinyatakan batal demi hukum atau dianggap tidak pernah ada perjanjian surogasi.

Hak waris anak yang dilahirkan akibat perjanjian surogasi dapat dilihat melalui status perkawinan ibu yang melahirkannya atau wanita surrogate, apabila wanita tersebut terikat perkawinan secara sah maka sesuai dengan undang-undang perkawinan anak tersebut memiliki hubungan perdata dengan suami wanita surrogate dan berhak mewaris pada suami tersebut, apabila wanita surrogate tidak dalam ikatan perkawinan maka anak tersebut berhak mewaris kepada ibu kandungnya atau wanita surrogate dan keluarga wanita surrogate, namun dengan adanya putusan Mahkamah Konstitusi Nomor 46/PUU-VIII/2010 ayah biologis atau ayah genetik dari anak tersebut wajib memberikan nafkah. Namun bukan tidak mungkin anak tersebut dapat mewaris kepada orang tua biologisnya, dengan pengangkatan anak yang dilakukan oleh orang tua biologis demi kepentingan yang terbaik untuk si anak, maka putuslah hubungan perdata anak tersebut dengan pihak wanita surrogate dan memiliki hubungan perdata serta berhak mewaris kepada orang tua angkat atau orang tua genetik atau biologis anak tersebut.

\section{Saran}

Untuk seluruh masyarakat Indonesia apabila mempunyai niat untuk melakukan perjanjian surogasi karena suatu alasan tertentu, sebaiknya dipertimbangkan kembali karena mengingat belum adanya aturan hukum yang terkodifikasi atau aturan yang khusus mengatur mengenai perjanjian surogasi. Apabila perjanjian surogasi ini tetap dilaksanakan tanpa pertimbangan mendalam, maka ditakutkan akan mengakibatkan timbulnya permasalahan hukum bagi pihak-pihak yang melakukan perjanjian dan anak yang lahir akibat perjanjian tersebut. Untuk pemerintah, mengingat semakin terbukanya situs surrogate mother diiringi dengan tingginya minat masyarakat Indonesia untuk menggunakan jasa sewa rahim ataupun menyewakan rahimnya karena suatu alasan atau kondisi apapun, hendaknya pemerintah segera merumuskan regulasi perundang-undangan yang secara khusus mengatur perjanjian surogasi dan praktik metode surogasi dalam dunia kesehatan baik yang bersifat perdata atau pidana sehingga terciptanya keadilan, kemanfaatan, dan kepastian hukum dalam masyarakat terkait memperoleh keturunan dengan perjanjian atau metode surogasi ini.

\section{DAFTAR PUSTAKA}

Arvidsson, A., Johnsdotter, S., Emmelin, M., \& Essén, B. (2019). Being Questioned as Parents: An Interview Study with Swedish Commissioning Parents Using Transnational Surrogacy. Reproductive Biomedicine and Society Online, 8, 23-31.

Chiang, W. T., \& Chou, T. Y. (2018). A survey of Judicial Decisions concerning Surrogacy Disputes in Taiwan. Taiwanese Journal of Obstetrics and Gynecology, 57(4), 517-521.

Crockin, S. L., Edmonds, M. A., \& Altman, A. (2020). Legal Principles and Essential Surrogacy Cases Every Practitioner Should Know. Fertility and Sterility, 113(5), 908-915.

González, N. I. (2020). Legal and Ethical Issues in Cross-Border Gestational Surrogacy. Fertility and Sterility, 
$113(5), 916-919$.

Ibrahim, J. (2013). Teori dan Metodelogi Penelitian Hukum Normatif (7th ed.). Malang: Banyumedia Publishing.

Judiasih, S. D., \& Dajaan, S. S. (2017). Aspek Hukum Surrogate Mother dalam Perspektif Hukum Indonesia. Jurnal Bina Mulia Hukum, 1(2), 141-150.

Klock, S. C., \& Lindheim, S. R. (2020). Gestational Surrogacy: Medical, Psychosocial, and Legal Considerations. Fertility and Sterility, 113(5), 889-891.

Tereshchenko, L. G., Sur, S., Meoni, L., Gambhir, T., Maly, M., Jaar, B., ... Parekh, R. (2015). Increased QT Variability Index is Associated with Mortality in Incident Hemodialysis Patients. Journal of the American College of Cardiology, 65(10S), A338.

Undang-Undang Dasar Negara Republik Indonesia Tahun 1945

Kitab Undang-Undang Hukum Perdata (Burgerlijk Wetboek)

Undang-Undang Republik Indonesia Nomor 1 Tahun 1974 tentang Perkawinan

Undang-Undang Republik Indonesia Nomor 36 Tahun 2009 tentang Kesehatan

Peraturan Menteri Kesehatan Republik Indonesia Nomor 43 Tahun 2015 tentang Penyelenggaraan Pelayanan Reproduksi dengan Bantuan atau Kehamilan di Luar Cara Alamiah

Peraturan Pemerintah Republik Indonesia Nomor 54 Tahun 2007 tentang Pelaksanaan Pengangkatan Anak

Peraturan Pemerintah Republik Indonesia Nomor 61 Tahun 2014 tentang Kesehatan Reproduksi

Putusan Mahkamah Konstiusi Nomor 46/PUU-VIII/2010 